\title{
Český príspevok k ochrane prírody, krajiny a pamiatok na Slovensku v r. 1918-2018
}

\section{Mikuláš Huba}

Envigogika 13 (2) - Inspirace /Inspiration

Publikováno / Published 28.10. 2018

DOI: $\underline{10.14712 / 18023061.577}$

\begin{abstract}
Abstrakt
Český príspevok k rozvoju Slovenska vo všetkých relevantných oblastiach bol v uplynulom storočí, ale najmä v r. 1918-1939, zásadný. Bez neho nie je fungovanie Slovákov ako štátotvorného národa predstavitel'né. Ide o historický fakt, ktorý nevidí iba ten, kto ho nechce vidiet'. Toto konštatovanie sa týka aj ochrany prírody, krajiny a pamiatok.
\end{abstract}

\section{Klíčová slova}

Ochrana př́rody; Československo; ochrana krajiny, ochrana památek; historie

\begin{abstract}
The Czech contribution to the development of Slovakia in all relevant fields has been essential in the past century, especially in the period 1918-1939. Without it, the Slovak nation would not have played such an active role in nation-building. This is an historical fact that invisible only to those who do not want to see it. This argument is also relevant for the protection of nature, landscapes and monuments.
\end{abstract}

\section{Key Words}

Nature protection; Czechoslovakia; landscape protection; protection of monuments; history 


\section{Z histórie (roky 1918-1939)}

Ako konštatuje V. Stockmann (2016) to, čomu dnes hovoríme ochrana prírody a krajiny na Slovensku, spadalo za čias Rakúsko-Uhorska (teda do r. 1918) pod budapeštiansku Štátnu pamiatkovú komisiu.

K vytvoreniu samostatných slovenských pamiatkových orgánov došlo až v r. 1919 pod názvom Vládny komisariát na ochranu pamiatok na Slovensku.

Komisariát sídlil v Bratislave. Za jeho vznikom stáli také osobnosti, ako významný pamiatkár-teoretik a sekčný šéf na pražskom Ministerstve školstva a národnej osvety, Zdeněk Wirth, historik umenia Jan Hofman a známy (česko)slovenský architekt Dušan Jurkovič.

Komisariát vznikol vládnym nariadením č. 155-1919 z 20. 10. 1919. V par. 1 tohto nariadenia sa píše: „Ochranou výtvarných pamiatok umeleckých, historických, l'udových i pamiatok prírodných a ochranou svojrázu kraja a domoviny na Slovensku poveruje sa Vládny komisariát na ochranu pamiatok na Slovensku a prikazuje sa mu právomoc bývalej uhorskej komisie. Tomuto úradu prislúcha spolurozhodovat́ vo všetkých záležitostiach, ktoré priamo alebo nepriamo majú vplyv na ochranu pamiatok. Úrady štátne i autonómne sú povinné $v$ takých prípadoch ho uvedomit' a vec predostriet'. Proti protestu Vládneho komisariátu na ochranu pamiatok na Slovensku nie je možné tieto záležitosti vybavit".

Komisariát pod vedením Jana Hofmana osobitne nariadil o.i. aj ochranu historických parkov. Významní štátni konzervátori: Wagner, Mencl, Dvořák...

Možno súhlasit' s V. Stockmannom, že toto vládne nariadenie bolo vel'mi pokrokové a tvorilo právnu i praktickú základňu ochrany prírody a krajiny na Slovensku na nasledujúce takmer dve desat'ročia.

V chápaní rozsahu pamiatkovej starostlivosti predstavovalo toto nariadenie velký pokrok v porovnaní s uhorským pamiatkovým zákonom č. 39-1881. A to tým, že do pôsobnosti novo vzniknutého komisariátu boli okrem umelecko-historických pamiatok začlenené aj historické, technické, urbanistické, l'udové a prírodné pamiatky, takže komisariát sa stal pracoviskom zameraným na ochranu nielen pamiatok v úzkom slova zmysle, ale - aspoň čiastočne - aj na ochranu prírody a krajiny v širšom zmysle ( v r. 1923 sa Vládny komisariát transformoval do podoby Štátneho referátu na ochranu pamiatok na Slovensku).

Už prvá etapa prác Vládneho komisariátu spočívala vo vypracovaní Koncepcie pamiatkovej starostlivosti, ochrany a zvelad'ovania krajiny. Vzápätí (v r. 1920) vznikol Návrh zákona na ochranu prírodných pamiatok na Slovensku. Jeho autorom bol známy český prírodovedec Jan Roubal.

Jeho prijatie sa, žial', nepodarilo presadit', ale jeho znenie je dôkazom toho, na akej výške bolo uvažovanie o ochrane pamiatok, prírody a krajiny v tom období v bývalom Československu. Na tento návrh nadväzuje Návrh osnovy nariadenia o ochrane prírody na Slovensku z r. 1935. Jeho prijatiu napokon zabránil zánik I. Československej republiky.

Podobne neúspešne dopadol aj pokus o prijatie osnovy zákona o ochrane prírody a krajiny (kde sa po prvý raz v názve legislatívneho aktu explicitne objavil pojem krajina - pozn. aut.) z r. 1945. 
Niečo z toho sa predsa podarilo doviest́ do úspešného konca. V roku 1923 sa vyšiel výnos ministra s plnou mocou pre správu Slovenska o ochrane prírodných pamiatok č. 7739prez. 1923, ktorým sa vyhlasuje ochrana krasových oblastí (krasovej krajiny) na Slovensku.

Významnú úlohu v tejto oblasti zohrali konzervátori ochrany prírody s kompetenciou vykonávat' dozor nad ochranou prírodných pamiatok na Slovensku. Riadili sa Pokynmi pre agendu konzervátorov Štátneho referátu na ochranu pamiatok na Slovensku.

Ďalšia významná postava českého pôvodu s mimoriadnymi zásluhami o ochranu prírody na Slovensku bol prof. Karlovej univerzity v Prahe, Karel Domin. Botanik, rektor, politik a otec myšlienky Tatranského a Pieninského národného parku.

\section{Roky 1945-1989}

Po II. svetovej vojne sa ochrana prírody a pamiatok v ČR a SR od seba oddialili, čo dokumentujú aj samostatné zákony, ktoré sa nimi v oboch republikách zaoberajú (pre viac info pozri napr. Klinda (2016) alebo Huba, Kubišová (2017).

Vel'a pre Slovensko pred II. sv. vojnou i po nej urobil prof. Josef Vydra. Z etnografov napr. Dr. Jiří Langer.

Fenomén sui generis na pomedzí umenia, vedy a osvety je Karel/Karol Plicka. Fotograf, režisér, zberatel' l'udových piesní, pedagóg, propagátor, organizátor...

Za vel'kého slovenského vlastenca - ochranára českého pôvodu považujem Pavla Šremera a jeho pražské ekodisidentské „dvojča", Ivana Dejmala.

České korene mali viacerí bratislavský ochranári. Od Jara Šíbla či Jirku Kubáčka, cez Vlada Iru a Kamila Procházku až po p. Břetislava Nováka, ktorý celé roky obetavo spravoval sekretariát bratislavských ochranárov.

Ale úzko sme spolupracovali aj s d’alšími, najmä v Brne (Lacina, Buček, Vlašín, Kundrata, Librová...), Prahe (Vavroušek, Bouzková, Makásek, Kára, Míchal, Moldan, Heyrovská), Olomouci (Nováček, Bartoš, Kysučan), Českých Budejoviciach (Tešitel, Johanisová), severných Čechách (Pakosta), južnej Morave (prevažne Brňáci), Krkonošiach (Kulichovci)...

Vel'kými témami s vel'mi aktívnou účast'ou českých ochranárov boli Dunaj v súvislosti s výstavbou Sústavy vodných diel Gabčíkovo - Nagymaros a neskôr aj Tatry či Devínska Kobyla. Začiatkom r. 1989 sa v Prahe konala pamätná česko-slovenská ochranárska konferencia: Životní prostředí hlavních měst (Praha-Bratislava), ktorá bola českou reakciou na vydanie publikácie Bratislava/nahlas a jej následnú podporu (aj.) z českých vedeckých a ochranárskych kruhov (pre viac info pozri napr. Huba (2008).

\section{Roky 1990 - 2018}

Ústredný orgán ani federálny zákon o životnom prostredí sme do r. 1990, resp. do začiatku r. 1992 v ČSFR nemali. To sa zmenilo až vznikom Federálneho výboru pre životné prostredie (FVŽP) a prijatím zákona č. 1/1992 Zb. Oba tieto počiny sa spájajú s menom Josefa Vavrouška, ktorý nás nielen za života, ale aj bezmála štvrt́storočie rokov po svojej smrti, dáva dohromady (o čom svedčia aj každoročné memoriály na počest' neho a jeho dcéry Petry). 
Josef Vavroušek založil aj tradíciu československých a neskôr i medzinárodných seminárov, venovaných udržatel'nému rozvoju, resp spôsobu života. Po jeho tragickom odchode štafetu po ňom prevzal najmä Pavel Nováček.

Miestom pravidelného stretávania sa českých a slovenských ochranárov boli oddávna Biele-Bílé Karpaty. Na túto tradíciu nadviazali po roku 1992 aj českí a slovenskí ochranári. V júni to bol spravidla dvojdenný seminár striedavo na slovenskej a moravskej strane, $v$ zime spoločný Silvester v Starom Hrozenkově, na Javorine a v Strání. Z (česko)moravskej strany sa žiada $v$ tejto súvislosti spomenút mená manželov Vavrouškovcov, Pavla Šremera, Erazima Koháka, Radka Kunca, Jany Hajduchovej, Milana Drgáča či Jardu Ungermana.

Tradične spolupracovali (a spolupracujú) českí a slovenskí ochranári v oblasti environmentálnej výchovy, vzdelávania a osvety. Stelesnením tejto spolupráce je naturalizovaný Trenčan, odchovaný Prahou, Richard Medal. Ale $v$ tejto súvislosti by sa žiadalo spomenút aj mená ako napr. manželia Dlouhý, Haisová, Bartoš, Kvasničková, Činčera a mnohé d’alšie.

A napokon (ale nie na poslednom mieste $v$ dôležitosti) do tohto obdobia spadá aj ambiciózny projekt, na začiatku ktorého stál tu už viackrát spomínaný Josef Vavroušek, a to spoločná výstava, katalóg a seminár českých a slovenských eko-výtvarníkov Identifikácia v priestore a čase, organizované v "triumviráte" STUŽ, Agentura Galerie H v Kostelci nad Černými lesy a Galéria M. A. Bazovského v Trenčíne.

\section{Záver}

Na niekolkých stranách textu sa nedá podrobne zmapovat́ problematika českej pomoci pri ochrane prírody, krajiny a pamiatok na Slovensku. Najmä, ak hovoríme o storočnici.

Išlo nám teda iba o pokus vystihnút charakteristické črty danej problematiky $v$ jednotlivých obdobiach a spomenút mená, ktoré sú objektívne, alebo sa nám aspoň zo subjektívneho hladiska javia, ako klúčové. Koexistencia "staršieho" a "mladšieho" brata nebola ani $v$ tejto oblasti bezproblémová, čo ju ale nediskvalifikuje. Napokon, po obnovení Československej republiky $v$ r. 1945 došlo k zásadnému osamostatneniu sa ochrany prírody, krajiny a pamiatok $v$ oboch republikách, čím sa eliminovalo aj riziko prípadných konfliktov, vztáahu nadradenosti a podradenosti či iných vývojových anomálií. Ale česká pomoc či už metodická, organizačná, vedecko-výskumná alebo pedagogická zostala aj nad’alej významná. A toto konštatovanie platí aj po 1. 1. 1993, kedy sa Československo rozdelilo na dva samostatné štáty.

\section{Literatúra}

- Huba, M. M. (2008): Ideál, skutočnost', mýtus - Príbeh bratislavského ochranárstva, PRO Banská Bystrica, $191 \mathrm{~s}$.

- Huba, M., Kubišová, K. (2017): Legislatívne aspekty ochrany charakteristického vzhl'adu (kultúrnej) krajiny v medzinárodnom kontexte (komparatívna štúdia). In: Ira, Hanušin (eds.): Premeny a ochrana historickej kultúrnej krajiny na Slovensku. Geographia Slovaca, 33, $31-58$. 
- Klinda, J. Uzákonenie ochrany prírody na Slovensku. Životné prostredie, 50, 209 212.

- Stockmann, V. (2016): Vývoj štátnej ochrany prírody na Slovensku v rokoch 1918 - 1938. Životné prostredie, 50, 195 - 204.

\section{Pod'akovanie}

Príspevok vznikol s podporou GP VEGA č. 2/0013/18 